\title{
The Historical Time Frame (Past 1000 Years)
}

\author{
Tadeusz Niedźwiedź, Rüdiger Glaser, Daniel Hansson, Samuli Helama, \\ Vladimir Klimenko, Ewa Łupikasza, Łukasz Małarzewski, Øyvind Nordli, \\ Rajmund Przybylak, Dirk Riemann, and Olga Solomina
}

\begin{abstract}
This chapter summarises the climatic and environmental information that can be inferred from proxy archives of the Baltic Sea area during the past millennium (1000 years). The proxy archives mainly comprise tree-ring analyses together with historical documents on extreme weather events and weather-related disasters. In addition to the reconstructed climate, climatic conditions are simulated using a regional climate model covering the Baltic Sea area. The chapter focuses on three of the main climatic periods of the past millennium: the Medieval Warm Period (900-1350), the Transitional Period (1350-1550) and the Little Ice Age (15501850). During these main historical climatic periods, climatic conditions were not uniform. Shorter warm/cool and wet/dry fluctuations were observed depending on regional factors.
\end{abstract}

\section{Keywords}

Millenium climate $\cdot$ Medieval warm period $\bullet$ Little ice age $・$ Baltic sea basin

T. Niedźwiedź ( $\square)$

Department of Climatology, University of Silesia,

Katowice, Poland

e-mail: tadeusz.niedzwiedz@us.edu.pl

R. Glaser · D. Riemann

Institut für Physische Geographie, Albert-Ludwigs-Universität Freiburg, Freiburg im Breisgau, Germany

D. Hansson

Swedish Institute for the Marine Environment, Göteborg, Sweden

S. Helama

Global Change Research Group-Arctic Centre, University of Lapland, Rovaniemi, Finland

\section{Klimenko}

Moscow Power Engineering Institute, Technical University, Moscow, Russia

E. Łupikasza $\cdot$ Ł. Małarzewski

Department of Climatology, University of Silesia,

Sosnowiec, Poland

Ø. Nordli

Research and Development Department, Norwegian

Meteorological Institute, Oslo, Norway

R. Przybylak

Department of Meteorology and Climatology, Nicolaus

Copernicus University, Toruń, Poland

O. Solomina

Institute of Geography of the Russian Academy of Sciences,

Moscow, Russia

\subsection{Introduction}

This chapter addresses climate variability in the Baltic Sea basin over the past millennium (1000 years). Climate change at the millennial time scale was not discussed in the previous assessment of climate change in the Baltic Sea region (BACC Author Team 2008).

Understanding of millennial climate variability is mainly based on proxy data (see Sect. 3.2). Historical notes in the form of chronicles containing information about extreme weather events, and weather-related disasters are important sources of data about climatic conditions in the past millennium. Together with historical documents, dendroclimatology has provided much of the information on the climatic conditions of the past millennium. Tree-ring width and wood density are the main sources of dendroclimatological data. Other proxy data are of less importance for the past millennium and are more relevant for reconstructing the climatic conditions of the Holocene as a whole. Temperature and precipitation data for the Baltic Sea region, as reconstructed from different proxy data sets were also compared against the results of a regional climate model simulation at the Swedish Meteorological and Hydrological Institute (Schimanke et al. 2012). The chapter also describes the main climatic drivers, of which solar radiation factors, atmospheric circulation patterns 
and volcanic eruptions appear the most important. The most unusual weather conditions in the Baltic Sea area in each century have been described in several publications (e.g. Rojecki 1965; Borisenkov and Pasetsky 1988, 2002; Pfister 1992, 1999; Glaser 2008).

\subsection{Data Sources and Methodology}

Research on millennial climate variability is mainly based on proxy data. This is because long-term instrumental measurements of meteorological elements (usually limited to atmospheric pressure, air temperature and wind) were recorded at only a few stations and over a relatively short period.

The first non-regular measurements of atmospheric pressure by means of a barometer constructed by Torricelli in 1643 were made in the period 1649-1658 in ClermontFerrand, Florence, Paris and Stockholm (von Rudloff 1967). The first regular meteorological measurements were launched in Greenwich (1774). The oldest continuous series of atmospheric pressure data for the Baltic Sea basin and surrounding areas date back to the nineteenth century: Prague (1800), Oslo (1816), Warsaw (1826), St Petersburg (1837), Copenhagen (1842), Stockholm (1844), Berlin (1848), Uppsala (1855), Haparanda (1859) and Helsinki (1882).

The first non-regular attempts at measuring air temperature began between 1654 and 1670 in Florence and Pisa in Italy (von Rudloff 1967); however, the longest homogenised and uninterrupted series of temperature data began in 1659 in central England (Manley 1974). In the Netherlands, direct temperature measurements started in 1705 in De Bilt (Cowie 2007). For the Baltic Sea basin, temperature measurements were initiated around the mid-1700s, with a denser coverage of the southern region in the late eighteenth century. The oldest continuous observational records of temperature are from Sweden: Uppsala (1739-non-regular measurements started in 1722), Lund (1741) and Stockholm (1756); Russia: St. Petersburg (1743); and Denmark: Copenhagen (1798) (von Rudloff 1967). A few temperature series began in the eighteenth century in central Europe: Berlin (1719), Jena (1770), Prague (1775), Warsaw (1779), Vilnius (1781), Wroclaw (1791) and Kraków (1792).

The oldest measurements of precipitation in Europe started in 1715 in Hoofddorp-Zwanenburg in the Netherlands and in 1725 in Padova in Italy. In the Baltic Sea area, the oldest precipitation station is Uppsala (1739) (von Rudloff 1967). In the first half of the nineteenth century, precipitation was also measured in a few other places: Warsaw (1803), Prague (1804), Copenhagen (1805), Jena (1827), Dresden (1828), Helsinki (1844) and Berlin (1847).

Historical notes in the form of chronicles containing information about extreme weather events and weatherrelated disasters are important sources of data about climatic conditions of the past millennium. In many cases, such notations are very precise as they locate events in space and time, sometimes even with an accuracy of a day. A systematic daily weather diary carried from 1502 to 1540 in Kraków and surroundings by Marcin Biem, a professor of Kraków Academy (Bokwa et al. 2001; Limanówka 2001) is unique on the European scale. A similar weather diary for the north-eastern part of Poland was kept by Jan Antoni Chrapowicki (Nowosad et al. 2007; Przybylak and Marciniak 2010) for the period 1656-1685. Borisenkov and Pasetsky $(1988,2002)$ compiled information about climate extremes and natural disasters from Russian chronicles. In Switzerland, Pfister (1992) established the European Centre of Historical Climate with the European Climate Historical database-EURO-CLIMHIST (Pfister 1992; Brázdil et al. 2010). Later, Glaser (2008) published the complete climate history for central Europe and Germany, covering the past 1200 years. Brázdil et al. (2005) discussed the state of European historical-climatological research with special attention to data sources, methods and significant results.

Together with historical documents, dendroclimatology has provided a large part of information on climatic conditions of the past millennium. Tree-ring width and wood density (Ljungqvist 2010) are the main sources of dendroclimatological data. Several recent multi-proxy reconstructions were made for the northern hemisphere (Jones et al. 1998, 2001a, b, 2009; Mann et al. 1998, 1999, 2008; Bertrand et al. 2002; Mann and Jones 2003; Jones and Mann 2004; Moberg et al. 2005; Ljungqvist 2010; Ljungqvist et al. 2012). On a regional scale, the most important reconstructions based on tree-ring or multi-proxy data are for Fennoscandia (Briffa et al. 1992; Gouirand et al. 2008; Lindholm et al. 2009, 2011; Esper et al. 2012), Finland (Helama et al. 2002, 2005, 2009b; Ogurtsov et al. 2008; Luoto and Helama 2010), central and northern Sweden (Gunnarson and Linderholm 2002; Linderholm and Gunnarson 2005; Moberg et al. 2006; Grudd 2008), eastern Norway (Kalela-Brundin 1999), Germany (Glaser 2008; Glaser and Riemann 2009), the north-western Baltic Sea (Klimanov et al. 1985), Russia (Klimenko and Solomina 2010), and Poland (Przybylak et al. 2005, 2010; Przybylak 2007, 2011; SzychowskaKrąpiec 2010; Koprowski et al. 2012). Although many of the data sets concern the Alps (Büntgen et al. 2005, 2006), they are well correlated with the central European mountains (Bednarz 1984, 1996; Bednarz et al. 1999; Niedźwiedź 2004; Büntgen et al. 2007, 2012).

Other proxy data were also applied to the millennium temperature reconstructions, for example, peat-bog deposits (Lamentowicz et al. 2008, 2009), lake fossils and sediments from Tsuolbmajavri Lake in northernmost Finland (Korhola et al. 2000), laminated lake sediments in Gościąż Lake in central Poland (Starkel et al. 1996; Ralska-Jasiewiczowa et al. 1998) and borehole temperatures (Majorowicz et al. 2004; 
Majorowicz 2010). The reliability of the reconstructions is discussed by Holmström (2011). For northern Sweden, a summer-temperature reconstruction for the past 2000 years was achieved using pollen-stratigraphical data (Bjune et al. 2009). Among other biological proxies, a few reconstructions were based on diatoms (Korhola et al. 2000; Weckström et al. 2006) and chironomids (Korhola et al. 2002). These data are of less importance for reconstructing the climatic conditions of the past millennium and better used for reconstructing the climate of the Holocene as a whole.

Proxy records are clearly useful for helping understand the spatial and temporal variability of climate change, especially over periods shorter than the millennial time frame and which fall outside the instrumental period. Other data sets, such as long-term variability in Baltic Sea ice cover (Koslowski and Glaser 1999), runoff or oxygen conditions (Hansson and Omstedt 2008; Hansson et al. 2011; Hansson and Gustafsson 2011) can be used in combination with climate models to increase understanding.

\subsection{General Features of the Millennial Climate}

According to the scientific literature, four climatic periods have occurred over the past millennium (Lamb 1977, 1982; Grove 1988; Folland et al. 1990; Brázdil 1996; Crowley 2000; Crowley and Lowry 2000; Bradley et al. 2003; Brázdil et al. 2005; Xoplaki et al. 2005; NCR 2006; Esper and Frank
2009; Jones et al. 2009; Brázdil and Dobrovolný 2010; Büntgen and Tegel 2011; Büntgen et al. 2011b; Ogurtsov et al. 2011; Przybylak 2011; Ljungqvist et al. 2012):

- Medieval Warm Period (MWP 900-1350) or Medieval Climate Anomaly (MCA)

- Transitional Period (TP 1350-1550)

- Little Ice Age (LIA 1550-1850)

- Contemporary Warm Period (CW after 1850).

The dates for the four climatic periods are approximate and may differ slightly from one geographical region to another (Ljungqvist et al. 2012). Some shorter intervals are mainly related to the changes in solar activity or large volcanic eruptions. The Contemporary Warm Period is addressed in detail in Chaps. 4-9.

A comparison of late spring (April-June) precipitation and summer (June-August) air temperature across Europe between the southern Baltic Sea and the Alps (Fig. 3.1) was reported by Büntgen et al. (2011b) for the last 2500 years, together with possible impacts on civilisation.

Gouirand et al. (2008) reported variability in summer temperature for the whole of Fennoscandia (Fig. 3.2) over the past 1500 years. All four periods of the past millennium (MWP, TP, LIA and CW) are visible. The curves for central Europe (Fig. 3.1) and Fennoscandia (Fig. 3.2) show similarities but the deepest cooling in Fennoscandia is observed at the beginning of eighteenth century, while in central Europe summer temperature, negative anomalies are higher in the first decades of the nineteenth century. Also, a cool episode during the MWP in the first half of the twelfth century in Fennoscandia is sharper than in central Europe.

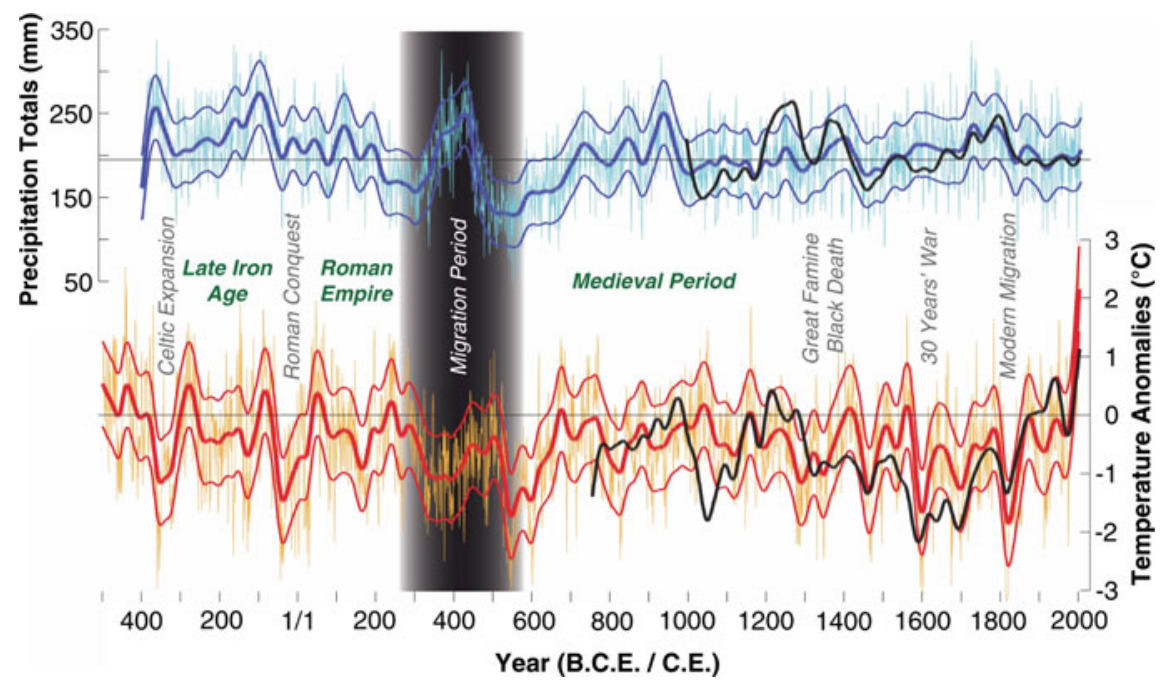

Fig. 3.1 Reconstructed April-June (AMJ) precipitation totals (top) and summer (June-August) temperature anomalies (bottom) for central Europe with respect to 1901-2000. Error bars are \pm 1 RMSE (RootMean Square Error) for the calibration periods. Black lines show independent precipitation and temperature reconstructions from
Germany (Büntgen et al. 2010) and Switzerland (Büntgen et al. 2006). Bold lines are 60-year low-pass filters. Periods of demographic expansion, economic prosperity and societal stability are noted, as are periods of political turmoil, cultural change and population instability. Büntgen et al. (2011b) 


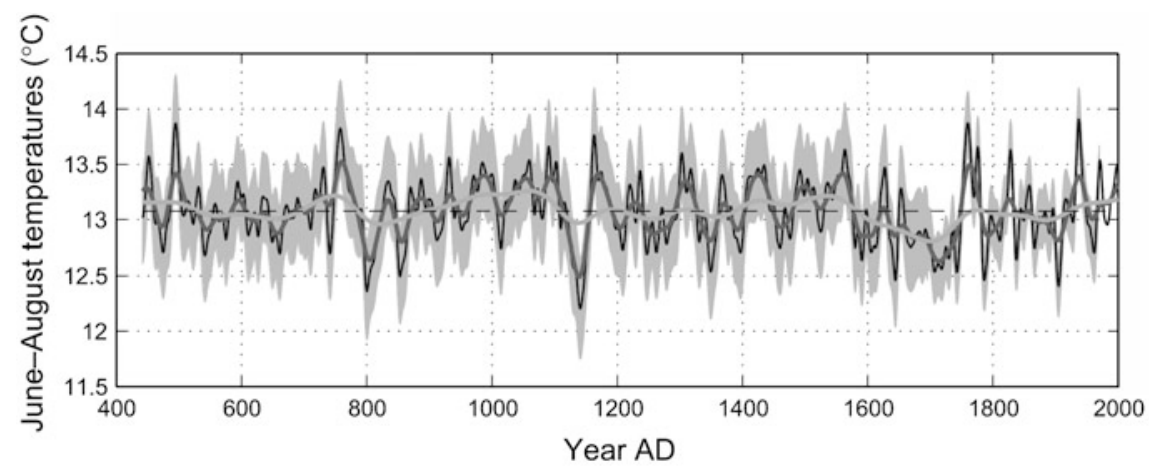

Fig. 3.2 Regional-average summer (June-August) temperatures $A D$ 442-1970 for Fennoscandia created by merging seven reconstructions based on seven networks (Gouirand et al. 2008). The time series is extended to year 2000 with instrumental data. Data are shown as smoothed (Gaussian filtered) temperatures, highlighting variability on timescales longer than 10 years (thin black), 30 years (thick dark grey) and 100 years (thick light grey). The dashed horizontal line is the average for the entire period. The uncertainty in reconstructed temperatures (based on the calibration period statistics) is illustrated by \pm 2 standard errors with grey shading (for the 10-year smoothing only)
Mean January-April air temperature for the period 11701994 (Fig. 3.3) and 10-year anomalies of winter and summer air temperature from 1401 to 1800 (Fig. 3.4) have been reconstructed for Poland. The climatic history for Poland over the past millennium was reconstructed by Przybylak (2011) and more comprehensively by Przybylak et al. (2010). Tree-ring reconstruction of January-April air temperature indicates three relatively cool periods: $1475-1500$, 1600-1660 and 1725-1830 (Fig. 3.3). The peak temperature of an exceptionally warm episode occurring $1661-1675$ is slightly lower than indicated by other reconstructions for central Europe (compare Fig. 3.9). Cold anomalies for winter temperature in Poland (Fig. 3.4) suggest an increased annual temperature range during the LIA. A cool period at the final phase of the LIA in the first half of the nineteenth century is also found in a reconstruction based on the full depth of ground temperature in boreholes (Majorowicz et al. 2004).

Climate change during the past millennium over the Baltic Sea region was simulated by the Swedish Meteorological and Hydrological Institute using a regional climate model (Schimanke et al. 2012). The authors used the Rossby Centre Regional model (RCA3) with boundary conditions from the general circulation model ECHO-G. RCA3 includes radiative forcing, changes in orbital parameters, changes in greenhouse gas concentration and atmospheric circulation. The model covers the whole Baltic Sea area and its surroundings and has a horizontal resolution of about $50 \times 50 \mathrm{~km}$. Results were presented as 50-year running means; air temperature is largely underestimated (Schimanke et al. 2012). Biases in annual precipitation are about $20 \%$ in the Baltic Sea region and during winter and autumn exceed $50 \%$.

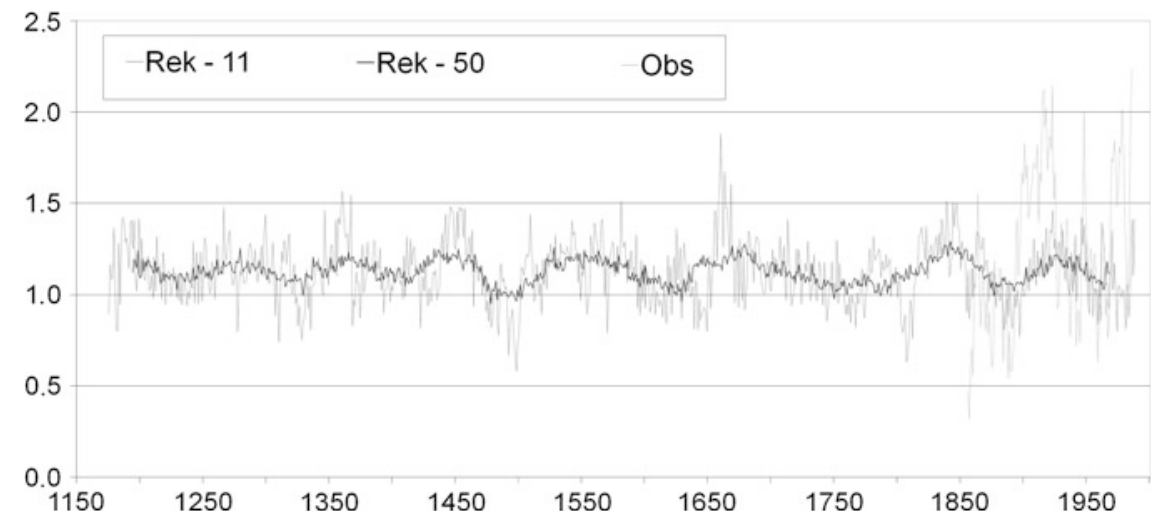

Fig. 3.3 Reconstructed mean January-April air temperature in Poland for the period 1170-1994 using a standardised chronology of Scots pine (Pinus sylvestris L.) tree-ring widths (modified after Przybylak et al. 2005; Przybylak 2011). Rek-11 and Rek-50 represent 11- and 50-year running means; reconstruction using areally averaged air temperature from Warsaw, Bydgoszcz and Gdańsk for calibration. Obs: measured mean January-April area-averaged air temperature from Warsaw, Bydgoszcz and Gdańsk (Przybylak et al. 2005; Przybylak 2007, 2011) 
Fig. 3.4 Reconstructed mean 10-year air temperature in Poland from 1401 to 1840 based on historical sources winter $(D J F)$ and summer $(J J A), 1$ and 2 anomalies with respect to 1901-1960 and 1789-1850 means, respectively. Przybylak (2011)

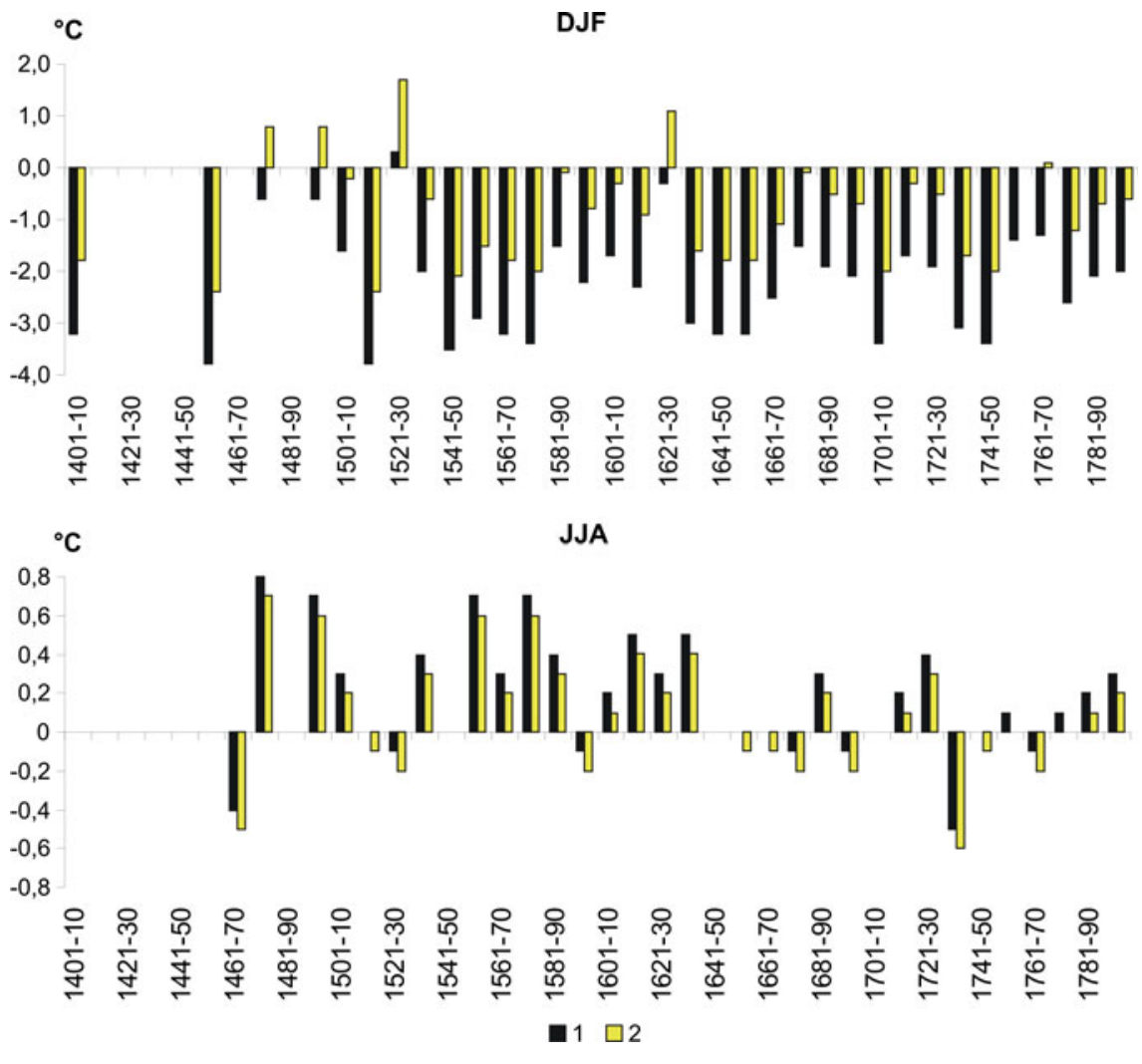

The 50-year running means for the annual temperature anomalies over Sweden varied from $-0.5{ }^{\circ} \mathrm{C}$ in the seventeenth century during the LIA to about $+0.4{ }^{\circ} \mathrm{C}$ in twelfth to thirteenth centuries representing the MWP (Fig. 3.5). The TP is clearly expressed by anomalies varying from about $0{ }^{\circ} \mathrm{C}$ through the fourteenth century to about $-0.2^{\circ} \mathrm{C}$ at 1550 .

Winter temperature anomalies are larger ranging from about $-0.9^{\circ} \mathrm{C}$ in 1700 to $+0.8{ }^{\circ} \mathrm{C}$ at the middle of the twelfth century (Fig. 3.5). Variability in summer temperature anomalies is less than for the annual anomalies, ranging from $-0.3{ }^{\circ} \mathrm{C}$ in the early eighteenth century to $+0.3{ }^{\circ} \mathrm{C}$ during the MWP near the mid-twelfth century.

The variability in annual and winter temperature anomalies for the Baltic Sea region presented in Fig. 3.5 (Schimanke et al. 2012) differs from other reconstructions. Winter temperature anomalies are lowest in the latter half of the seventeenth century $\left(-0.9^{\circ} \mathrm{C}\right)$. This shows some agreement with the reconstructed winter temperatures for the greater Baltic Sea area (Eriksson et al. 2007) discussed in Sect. 3.5. A large discrepancy is visible in the first half of the eighteenth century when the reconstructed winter temperature anomaly is greatest in the LIA, while the model simulation indicates a warm episode near 1800, which Eriksson et al. (2007) suggested was the coolest in the LIA (based on 15year running means for temperature).

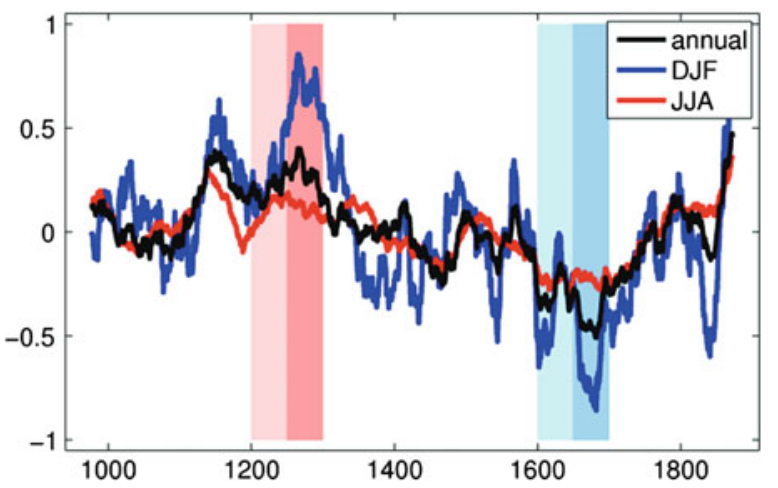

Fig. 3.5 The 2-m temperature anomaly with regard to the preindustrial mean (950-1900) for the winter $(D J F)$, summer $(J J A)$ and annual mean averaged over the Baltic Sea region. The coloured sections highlight the periods that are defined as MWP (red) and LIA (blue). The darker colours reflect the 50-year periods which are considered for the analysis of the Baltic Sea. After Schimanke et al. (2012)

Reconstructing past precipitation using proxy measurements is more difficult than for temperature and is only possible for parts of the year. There is no possibility of reconstructing annual precipitation data from proxy data. Büntgen et al. (2011b) reconstructed total precipitation from April to June for central Europe between the southern Baltic Sea and the Alps. Warm and dry summers are typical during 
Fig. 3.6 a Central European and regional fir TRW (Tree Ring Width) extremes, and $\mathbf{b}$ their centennial changes over the past millennium (network extremes were double weighted), compared to c annual-resolve and 40-year low-passed Central European April-June precipitation variability (Büntgen et al. 2011c)

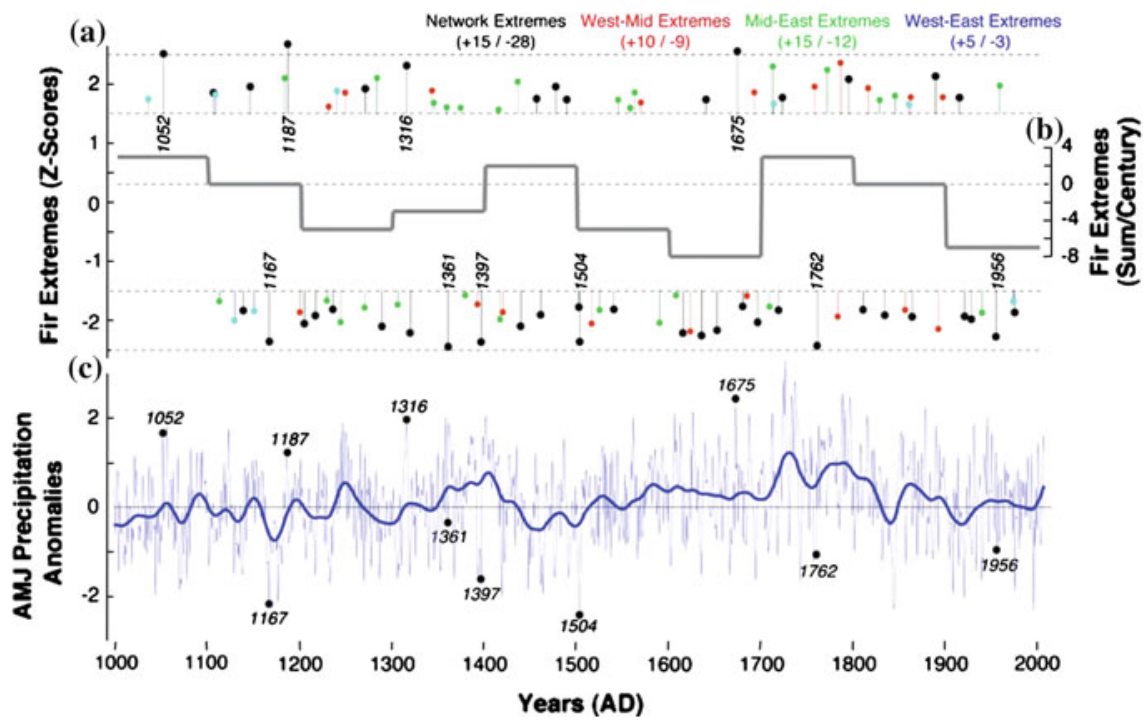

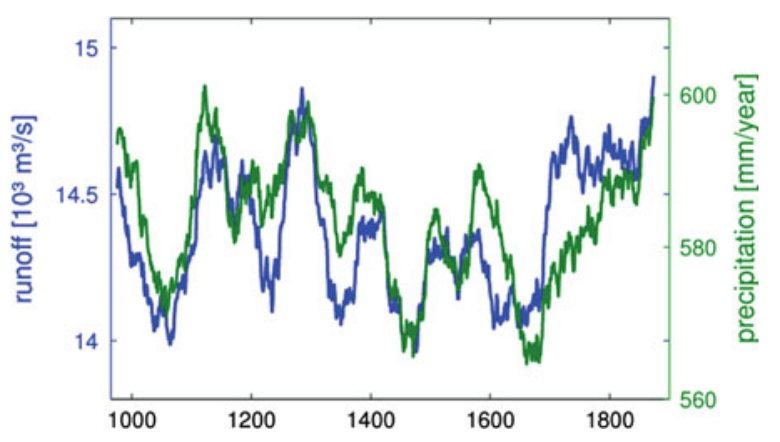

Fig. 3.7 Annual precipitation in the Baltic Sea catchment area (green) and statistical estimated runoff (blue) as 50-year running means. After Schimanke et al. (2012)

the MWP (900-1350). The onset of the TP in the latter half of the thirteenth century is indicated by cooler and wetter summers. Total precipitation between April and June over the past millennium in central Europe is presented in Figs. 3.1 (Büntgen et al. 2011b) and 3.6 (Büntgen et al. 2011c). Generally, the MWP was drier than the first half of the TP and the LIA in spring and early summer seasons.

Annual precipitation simulated in the Baltic Sea catchment area by a regional climate model (Schimanke et al. 2012) and shown in Fig. 3.7 indicates that the annual totals are larger during the MWP than the TP and the LIA. The annual precipitation data cannot be compared with the reconstructed data for April-June. However, the very dry period in the latter half of the fifteenth century is marked in both precipitation series. The variability of river runoff to the Baltic Sea follows changes in precipitation. However, the simulation of river runoff for the period $1500-1995$ by Hansson et al. (2011) presented in Chap. 5, Fig. 5.3 indicates no significant long-term change.

\subsection{The Medieval Warm Period (MWP 900-1350)}

At the turn of the tenth and eleventh centuries, relatively stable climate conditions with few extremes prevailed in the Baltic Sea basin and the surrounding parts of Europe. Hot and dry summers were noted in 993 and 994, respectively. For example, in Russian chronicles, eight droughts (1000, $1025-1028,1035,1037,1092)$, four wet summers with rain and floods $(1002,1031,1034,1043)$ and seven severe winters $(1034 / 35,1043 / 44,1047 / 48,1056 / 57,1058 / 59$, $1066 / 67,1076 / 77$ ) were noted in the eleventh century (Borisenkov and Pasetsky 1988, 2002).

In Europe, the warmest conditions occurred between 1200 and 1250, and the MWP ended about 1350 (Borisenkov and Pasetsky 1988, 2002). Chernavskaya (1996) reconstructed the June temperature changes in European Russia over the past two millennia based on pollen analysis in peat bogs. Data from Polistovo $\left(56.8^{\circ} \mathrm{N}, 38.1^{\circ} \mathrm{E}\right)$ suggest an earlier occurrence of the MWP (ninth to tenth centuries) in European Russia than in central Russia (tenth to eleventh centuries). Two periods of strong cooling occurred in the middle of the twelfth century and at the end of the fourteenth century. On the East European Plain, summer temperatures during the MWP were found to be above the long-term average between 900 and 1200 (Klimenko and Solomina 2010). For Fennoscandia (Fig. 3.2), summer temperatures were elevated in the tenth and eleventh centuries (Gouirand et al. 2008). Even warmer summer periods were noted in the late twelfth century, succeeding the extreme cool summers in the mid-twelfth century. 
Recent investigations of Fennoscandia by Ljungqvist (2010) showed that the MWP occurred between 800 and 1300. At that time, warm-season (May-September) temperatures exceeded the contemporary warming of the end of twentieth century by about $+0.5^{\circ} \mathrm{C}$. The start of the warming was noted between the ninth and tenth centuries, and the peak temperature appeared at the beginning of the second half of the twelfth century. In a winter temperature simulation over the Baltic Sea region (Schimanke et al. 2012) during that time anomalies reached their highest value of $+0.8{ }^{\circ} \mathrm{C}$ for the MWP (Fig. 3.5). Lower temperatures occurred at the end of the MWP, about 1350. A diatombased July temperature reconstruction for the past 800 years in northern Scandinavia (Weckström et al. 2006; Holmström 2011) indicates that temperature was about $0.2{ }^{\circ} \mathrm{C}$ higher in the latter half of the fifteenth century than in 1970-2000. An exceptionally warm period occurred in $1220-1250$ and in the latter half of the fifteenth century (1470-1500) in the TP. The frequency of extreme temperature events in Russia increased in the twelfth century (Borisenkov and Pasetsky 1988, 2002). Winter-simulated temperature indicates the second warm episode of the MWP in the latter half of the thirteenth century (Schimanke et al. 2012) for the Baltic Sea region (Fig. 3.5). At the beginning of the fourteenth century, climatic conditions cooled rapidly. In 1315, a serious famine in northern Europe resulted from a series of very cold winters (1302/03 and 1305/06) and cool and wet summers (1314-1317) across the whole of Europe (Cowie 2007).

There is less information available on precipitation in the MWP (Gouirand et al. 2008; Büntgen et al. 2011b, c). Nevertheless, a regional dendroclimatic precipitation reconstruction from southern Finland showed a uniquely prolonged rainfall deficit coinciding with the MWP (Helama et al. 2009a). The drought was particularly severe between 1000 and 1200. The simulation of annual precipitation for the Baltic Sea catchment using a regional climate model (Schimanke et al. 2012) shows that the driest period was the mid-eleventh century and that two wet periods occurred in the first half of the twelfth century and the latter half of the thirteenth century (Fig. 3.7). As a generalisation, relatively dry periods occurred in Europe in the years: 1272-1291, and 1300-1309, while the wettest conditions were noted in 1312-1322 (Borisenkov and Pasetsky 1988, 2002). In April-June in central Europe (Fig. 3.6), wet conditions were observed in 1052, 1187 and 1316, and the driest in 1167 (Büntgen et al. 2011c). Distinct wet periods with frequent floods were recognised in this region at 1020-1030 and 1075-1100 (Starkel 2001).

\subsection{The Transitional Period (TP 1350-1550)}

The increase in the intra-seasonal variability of climate at the end of the MWP in the period 1270-1350 is considered to be the beginning of the LIA; however, Brázdil et al. (2005) suggested that the following 200-year period should be treated as transitional between the MWP and the LIA. This period was characterised by a great variability of climatic conditions. At that time, temperature decreased by about $1.2{ }^{\circ} \mathrm{C}$, but cooling occurred until the latter half of the sixteenth century (Borisenkov and Pasetsky 1988, 2002). During this period, the decreasing tendency of mean annual and seasonal temperatures simulated for Baltic Sea region (Fig. 3.5) is clearly visible.

Over the majority of Europe and Russia, very unfavourable conditions for agriculture in the period 1400-1480 were linked to large fluctuations in temperature and precipitation. For example, the summers of 1428, 1434, 1436 and 1438 were hot and dry and the summer of 1435 was cool and dry, whereas the summers of 1432, 1437 and 1439 were extremely wet with flooding (Borisenkov and Pasetsky 1988, 2002). In central Europe (Fig. 3.6), the first part of the TP up to about 1430 was very wet according to the reconstructed April-June precipitation curve (Büntgen et al. 2011c) and followed by very dry conditions with an extremely dry and hot spring and summer in the year 1504 (Glaser 2008).

In Poland (Fig. 3.4), severe winters were detected in four decades: 1401-1410, 1451-1460, 1511-1520 and 15411550 (Przybylak 2011). The warmest were winters during the years 1521-1530. Similar thermal conditions in winter based on historical sources were found in Latvia (Jevrejeva 2001) and Estonia (Tarand and Nordli 2001). The summers were relatively warm in two decades: $1471-1480$ and 14911500.

The first halves of the fifteenth and sixteenth centuries appear relatively warm periods, but there was large variability (Helama et al. 2009b). Climatic variability may be reflected in the proxy instability. According to a diatombased reconstruction, the warmest 30-year non-overlapping period in northern Scandinavia occurred in 1470-1500 (Weckström et al. 2006); however, according to a dendroclimatic reconstruction in this region, the summers of the late fifteenth century were anomalously cold (Helama et al. 2009b). There were very warm conditions in Fennoscandia in summer at the end of the TP (Gouirand et al. 2008; Fig. 3.2). 


\subsection{The Little Ice Age (LIA 1550-1850)}

In the latter half of the sixteenth century, the temperature dropped. This tendency was particularly clear in the period 1569-1579. Another sequence of extremely wet and cool summers was identified at the end of the sixteenth century (Borisenkov and Pasetsky 1988, 2002). The longest consecutive cold period occurred from the late sixteenth century to the mid-eighteenth century (Gouirand et al. 2008), which is in very good agreement with a regional climate model simulation for temperature in the Baltic Sea region (Schimanke et al. 2012; Fig. 3.5). But a short sequence of very warm summers was observed in the latter part of eighteenth century, just before the prolonged cooling at the end of the eighteenth and during the nineteenth century (Fig. 3.2).

Eriksson et al. (2007) analysed the complex description of winter climate conditions during the LIA for the greater Baltic Sea region $\left(50-70^{\circ} \mathrm{N}, 0-30^{\circ} \mathrm{E}\right)$. Their study is based on well-documented time series of ice cover, sea-level pressure and winter surface-air temperatures. Using winter temperature in connection with atmospheric circulation and ice conditions, they found four cold and three warm periods during the LIA (Fig. 3.8). In the latter half of the sixteenth century, a cool phase (1562-1576) passed to a relatively mild period (1577-1591). In the seventeenth century, two phases of cold winters, 1597-1629 and 1663-1706, were
Fig. 3.8 Winter climate conditions in the greater Baltic Sea region since 1500 . The grey colour shows seasonal winter data from two gridded data sets: (top to bottom) Baltic Sea mean winter air temperature. Black line in all panels is a 15 -year running mean. Blue and red fields cover periods classified as cold and mild, respectively (Eriksson et al. 2007)

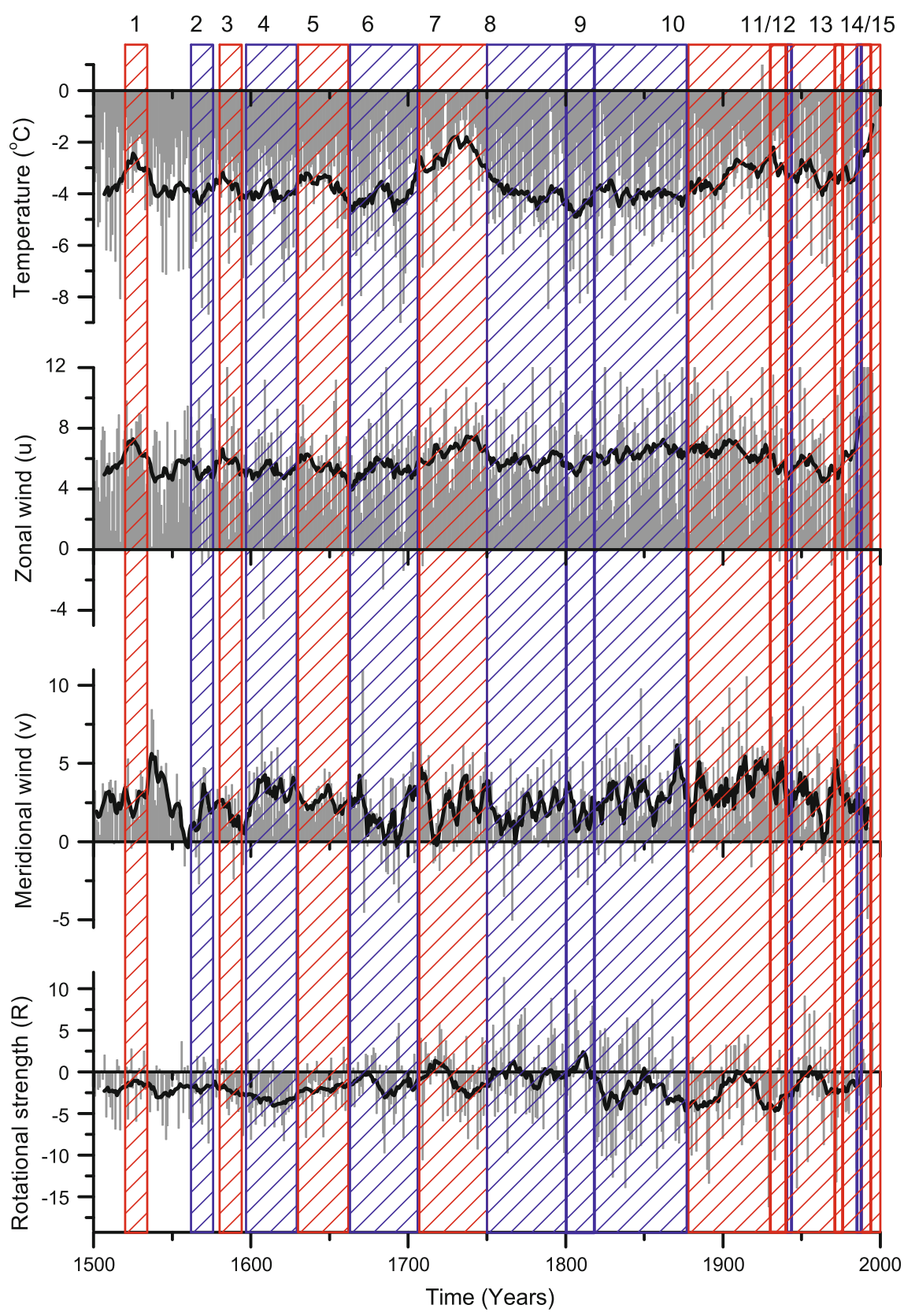


divided by the mild period of $1630-1662$. The first half of the eighteenth century (1707-1750) which includes the warmest winter $(1723 / 24)$ is considered to be the major warm period. At this time, the maximum ice extent in the Baltic Sea was similar to present-day conditions, albeit there are many uncertainties related to the observations at that time (Seinä and Palosuo 1996; Hansson and Omstedt 2008). The period 1730-1745 has also been described as particularly variable interannually, swinging from extremely mild to extremely cold winters (Jones and Briffa 2006). The occurrence of cold winters is related to the Late Maunder Minimum (1675-1715) which has also been discussed by Luterbacher et al. (2001) and in Chap. 4, Sect. 4.2.3. The longest cool period in the final phase of the LIA in the Baltic Sea region (1750-1877) coincided with the Dalton
Minimum (1790-1840) in solar activity (Eriksson et al. 2007; see also Chap. 4). During the entire LIA, no downward trend in ice break-up date of the river Daugava was detected (see also Chap. 5).

A new reconstruction of the Baltic Sea region climate for the past 500 years was prepared by Brázdil et al. (2010) on the basis of instrumental data and documentary evidence under the MILLENNIUM project. January-April mean temperatures were reconstructed for Stockholm (1502-2008) and central Europe (1500-2007). In central Europe, the coldest conditions were observed in the sixteenth century, while in central Sweden the end of the seventeenth century was cooler (Fig. 3.9). In central Europe, the warmest period was the first half of the eighteenth century, while in Stockholm such conditions occurred at the end of the eighteenth
Fig. 3.9 Comparison of reconstructed JFMA (January-April) temperatures for Stockholm (1502-2008) and CEuT (Central European Temperature) (1500-2007) (anomalies from the 1961-1990 mean). Original series of CEuT (a) and Stockholm (b) are smoothed with a 30-year Gaussian filter (c) and compared using 31-year running correlations between unfiltered data (d). The horizontal solid line in d denotes the critical value of correlation coefficients for $\alpha=0.05$ for one-tailed $t$ test (Brázdil et al. 2010)
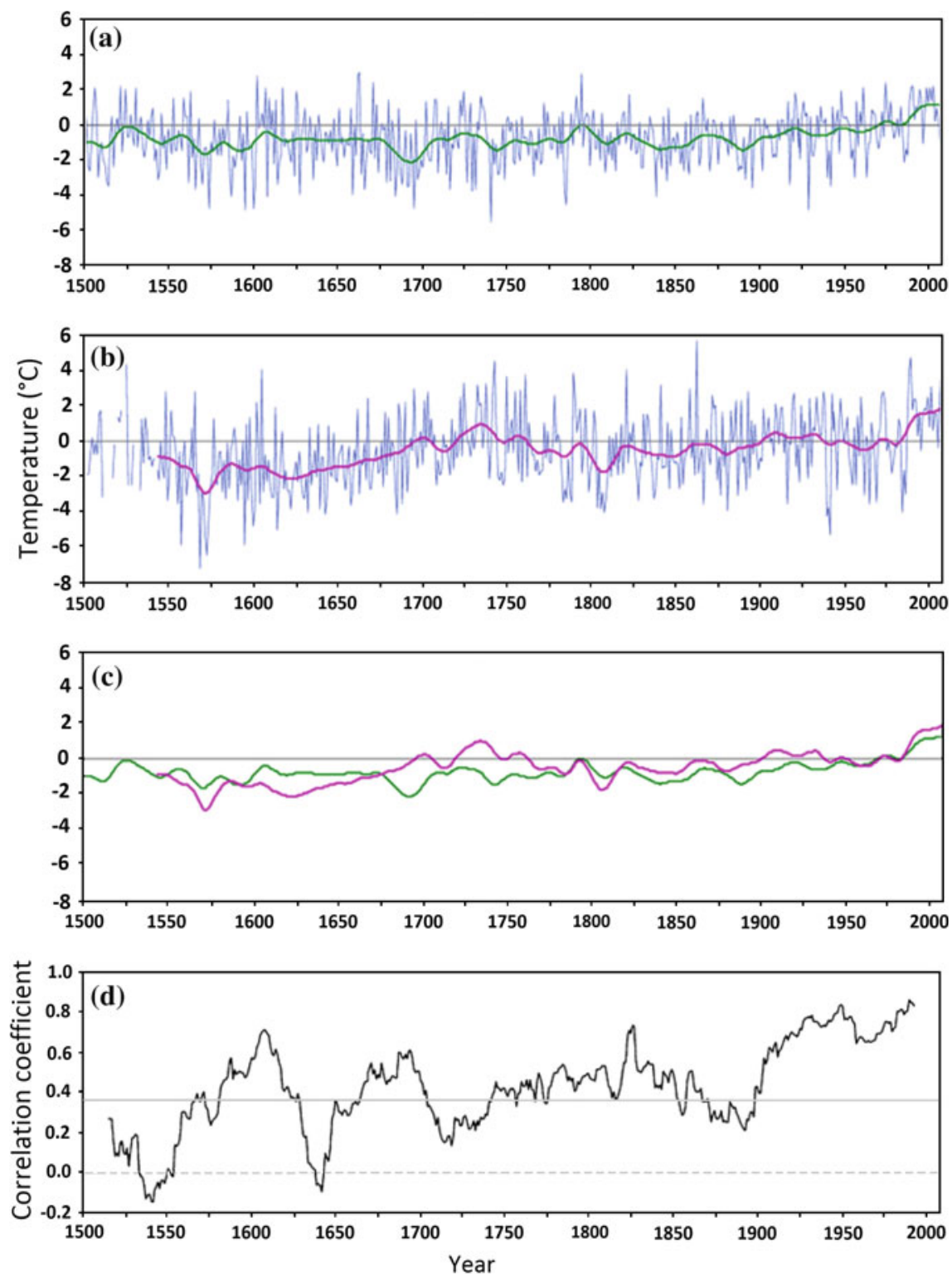


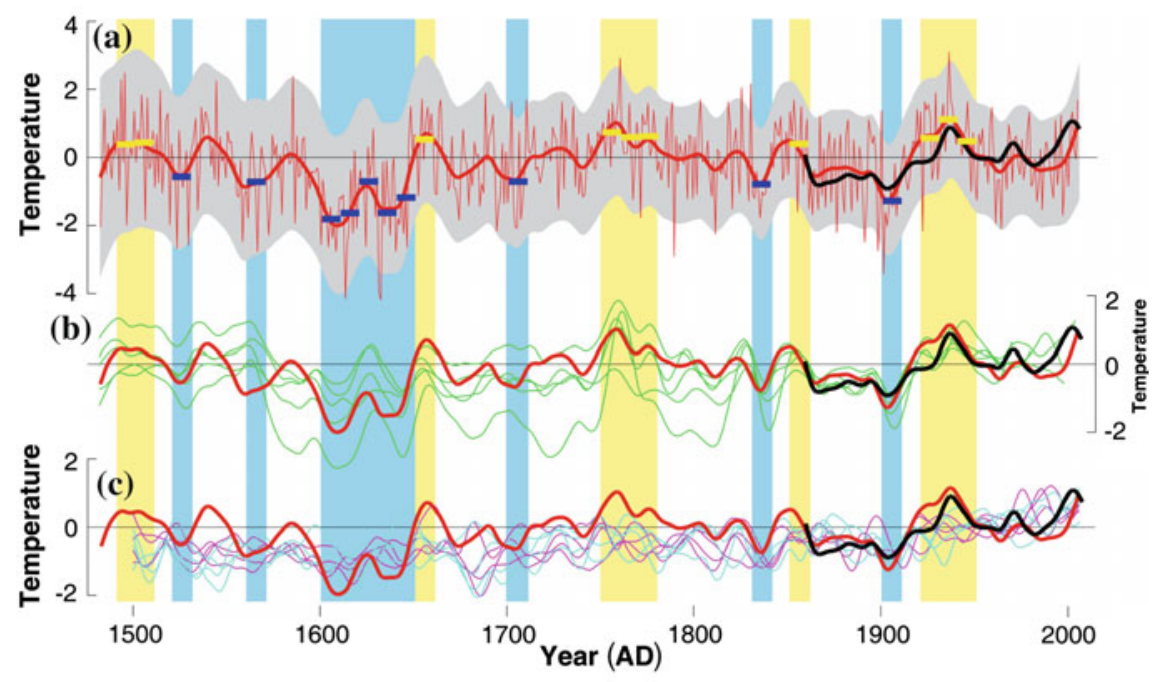

Fig. 3.10 Reconstructed and modelled northern Scandinavian summer temperature variations over the past five centuries (Büntgen et al. 2011a). a Actual (black) and reconstructed (red) JJA (June-August) temperature anomalies $\left({ }^{\circ} \mathrm{C}\right)$ with error estimates (grey) and the ten warmest and coldest decades superimposed (colour boxes). b Comparison of the actual and reconstructed temperatures with five existing

century. In the recently modelled and reconstructed northern Scandinavian summer temperatures since 1500 (Fig. 3.10), the longest cool period covered the first half of the seventeenth century (Büntgen et al. 2011a) and the beginning of the eighteenth century as well as in the early nineteenth century. The warmest conditions occurred just after the middle of the eighteenth century.

There are several climate reconstructions based on the documentary and instrumental data for the period since 1500. Koslowski and Glaser (1999) constructed an ice winter severity index and temperature for the western Baltic Sea region, covering the period of 1500-1759. Temperature series were reconstructed for Stockholm (Moberg et al. 2002; Leijonhufvud et al. 2010), Tallin (Tarand and Nordli 2001), Poland as a whole (Dobrovolný et al. 2010; Luterbacher et al. 2010; Przybylak et al. 2010) and the Tatra Mountains (Bednarz 1984; Niedźwiedź 2004; Büntgen et al. 2007), and several parts of central Europe (Pfister 1992; Brázdil 1996; Luterbacher et al. 2004; Dobrovolný et al. 2010).

Glaser et al. (2010) reconstructed the variability of floods in Europe since 1500. The precipitation conditions are presented in Figs. 3.1 and 3.6. The wettest conditions during the LIA were observed in 1675 (Glaser 2008) and the first half of the eighteenth century, and the driest were the years 1504 and 1762 (Büntgen et al. 2011c). In southern Finland, conditions were markedly wetter during the LIA than the MWP, (green) reconstructions. c Comparison of the actual and reconstructed temperatures with CCSM3 surface-air temperature (pink) and sea surface temperature (blue) model simulations. Mean and variance of the data are scaled against JJA temperature (1860-2006), expressed as anomalies (relative to 1961-1990) and 20-year low-pass filtered

as inferred from tree rings (Helama et al. 2009a). An exception was a period of transient drought which, as the same dendroclimatic reconstruction indicates, occurred during the first decades of the nineteenth century. A regional model simulation of annual precipitation (Schimanke et al. 2012) shows that the driest period of the LIA was the latter half of the seventeenth century (Fig. 3.7). For central-east Sweden the low May-June precipitation was found by Jönsson and Nilsson (2009) to occur in the periods 15601590 and 1694-1751. The clustering of heavy rainfall years is typical for the LIA, causing the floods in central Europe in 1590-1610, 1705-1715 and 1800-1815 (Starkel 2001). They coincide with the relatively cool periods of Spörer, Maunder and Dalton solar activity minima.

In the seventeenth century, the winter of $1657 / 58$ was exceptionally cool. Modelled Baltic Sea ice extent indicates that it was one of the coldest winters for the Baltic Sea since 1500 (Hansson and Omstedt 2008). The sequence of cool summers and winters occurred over the period 1690-1699. In Sweden, climatic conditions favourable for agriculture occurred in 1604-1620 (Borisenkov and Pasetsky 1988, 2002). According to a diatom-based July temperature reconstruction in Finnish Lapland (Weckström et al. 2006), particularly cold 30-year periods were detected between 1640-1670 and 1750-1780. In several reconstructions, the low-frequency variability of LIA temperature is underestimated (e.g. von Storch et al. 2004; Zorita et al. 2007; 
Christiansen and Ljungqvist 2011). A new method of temperature reconstruction (Christiansen and Ljungqvist 2011) showed that in the seventeenth century, the lowest temperature anomaly in the cooling northern hemisphere reached a 50-year smoothing value $1.1{ }^{\circ} \mathrm{C}$ below the contemporary level (1880-1960). The period 1630-1700 was the coolest consecutive period of the entire past millennium.

At the beginning of the eighteenth century, the winter of $1708 / 09$ was perhaps the coldest winter of the past 500 years (Luterbacher et al. 2004). In Poland, the coolest winters were recorded in the decades 1701-1710 and 1741-1750, while the coldest summers were found in the decade 1731-1740 (Przybylak 2011). Very cold winters were also observed at the end of eighteenth century in 1783/84, 1788/89, 1794/95 and 1798/99 (Borisenkov and Pasetsky 1988, 2002). This cold period continued to the end of the first half of the nineteenth century. In 1815, the Tambora volcanic eruption in Indonesia discharged large amounts of ash into the upper atmosphere, resulting in the famous 'year without a summer' in 1816. This particular year, the summer in western Europe was unusually cold. However, that was not the case in the Baltic Sea basin (Briffa and Jones 1992). In eighteenth century in Poland, precipitation showed large variability. The period 1731-1750 was wetter than normal (Przybylak 2011). But between 1751 and 1766 , during a generally dry period with 13 dry years, the wettest was 1755 and the driest 1762 .

Dendroclimatological studies have identified several cool and rainy summers in the Carpathian Mountains (southern Poland) in the latter part of the LIA: 1650-1660, 1670 1685, 1690-1719 and 1735-1745 (Bednarz 1984, 1996). The final phase of the LIA in the first half of the nineteenth century was also marked by a sequence of exceptionally cold years between 1812 and 1824. In that period, average winter temperature in Russia and a large part of Europe was lower than normal by as much as $10-12{ }^{\circ} \mathrm{C}$ (Borisenkov and Pasetsky 1988, 2002). In central Europe, the winter of 1829/ 30 was extremely cold, as well as the winters of 1822/23 and 1837/38. In Norway, based on farmer diaries (Nordli et al. 2003), the severely cold spring/summer (April-August) decadal temperatures were found around 1740, and the 1800 s and 1830s.

The cooling during the LIA had an important influence on human society. At the turn of the thirteenth and fourteenth centuries, the number of farms in northern Norway decreased due to a drop in temperature (Cowie 2007). In Finland, abandoning of farms in the sixteenth and seventeenth centuries coincided with a long-term summer temperature cooling, implying that the desertion may have resulted from a change in climatic conditions that significantly limited agriculture as a means of subsistence (Holopainen and $\mathrm{He}-$ lama 2009). In the same region, harvest records show that during the poorest years the amount of grain harvested was less than had been sown (Holopainen and Helama 2009). Very unfavourable weather conditions in 1697 resulted in a failed crop. This caused widespread famine, followed by over a third of the Finnish and a fifth of the Estonian population dying in just a few years (Cowie 2007). Also, the cold winter of $1657 / 58$ permitted the Swedish King Charles $\mathrm{X}$ to walk across the frozen Belts and Sound with his army and occupy all of Denmark, except for Copenhagen, with a large loss of land for the Danish (Neumann 1978; Hansson and Omstedt 2008).

There are discrepancies in the dates of both the end of the LIA and the beginning of the CW. The majority of scientists agree on 1850 as being crucial (e.g. Grove 1988). However, some climatologists claim that the LIA did not finish until the last decades of the nineteenth century (e.g. Lamb 1977). In southern Poland (Tatra Mountains) according to summer temperature data, the final episode of the LIA lasted 103 years: 1793-1895 (Niedźwiedź 2004).

\subsection{Conclusion}

According to the scientific literature, there are four climatic periods of the past millennium: the Medieval Warm Period (MWP 900-1350), the Transitional Period (TP 1350-1550), the Little Ice Age (LIA 1550-1850), and the Contemporary Warm Period (CW after 1850). The MWP started at the beginning of the tenth century with relatively stable climate conditions, and few extremes prevailed in the Baltic Sea basin and the surrounding parts of Europe. The warmest conditions occurred between 1200 and 1250. Two periods of strong cooling were detected in the middle of the eleventh and at the beginning of the fourteenth century. During the MWP in Fennoscandia, warm-season (May-September) temperatures exceeded the contemporary warming of the end of twentieth century by about $+0.5^{\circ} \mathrm{C}$. The following 200year period should be treated as a transitional period between the MWP and LIA. This period was characterised by a great variability in climatic conditions; at that time, temperature decreased by about $1.2^{\circ} \mathrm{C}$. In the latter half of the sixteenth century, the temperature dropped, initiating the LIA. Winter temperatures in combination with atmospheric circulation and ice conditions indicate four cold and three warm periods during the LIA. In the recently modelled and reconstructed northern Scandinavian summer temperatures since 1500, the longest cool period prevailed during the first half of the seventeenth century and at the beginning of the eighteenth century, as well as during the first years of the nineteenth century. During these main historical climatic periods, climatic conditions were not uniform. Shorter warm/cool and wet/dry fluctuations were observed depending on regional factors. 
Open Access This chapter is distributed under the terms of the Creative Commons Attribution Noncommercial License, which permits any noncommercial use, distribution, and reproduction in any medium, provided the original author(s) and source are credited.

\section{References}

BACC Author Team (2008) Assessment of Climate Change for the Baltic Sea Basin. Springer-Verlag, Berlin Heidelberg

Bednarz Z (1984) The comparison of dendroclimatological reconstructions of summer temperatures from the Alps and Tatra Mountains from 1741-1965. Dendrochronologia 2:63-72

Bednarz Z (1996) June-July temperature variation for the Babia Góra National Park, southern Poland, for the period 1650-1910. In: Obrębska-Starkel B, Niedźwiedź T (eds), Proceedings of the International conference on climate dynamics and the global change perspective, Cracow, 17-20 October 1995. Institute of Geography of the Jagiellonian University, Prace Geograficzne 102:523-529

Bednarz Z, Jaroszewicz B, Ptak J, Szwagrzyk J (1999) Dendrochronology of Norway spruce (Picea abies L. Karst.) in the Babia Góra National Park, Poland. Dendrochronologia 16:45-55

Bertrand C, Loutre M-F, Crucifix M, Berger A (2002) Climate of the last millennium: a sensitivity study. Tellus A 54:221-244

Bjune AE, Seppa H, Birks HJB (2009) Quantitative summer-temperature reconstructions for the last 2000 years based on pollenstratigraphical data from northern Fennoscandia. J Paleolimnol 41:43-56

Bokwa A, Limanówka D, Wibig J (2001) Pre-instrumental weather observations in Poland in the $16^{\text {th }}$ and $17^{\text {th }}$ centuries. In: Jones PD, Ogilvie AEJ, Davies TD, Briffa KR (eds), History and climate. Memories of the future? Kluwer/Plenum Publishers, New York, Boston, Dordrecht, London, Moscow, p 9-27

Borisenkov YeP, Pasetsky VM (1988) Millennium-long chronicle of unusual natural events. Mysl, Moscow (in Russian)

Borisenkov YeP, Pasetsky VM (2002) Long chronicle of unusual natural events for 2.5 millennia $\left(5^{\text {th }}\right.$ Century BC $-20^{\text {th }}$ Century AD). Gidrometeoizdat, St Peterburg, (in Russian)

Bradley RS, Hughes MK, Diaz HF (2003) Climate in Medieval time. Science 302:404-405

Brázdil R (1996) Reconstructions of past climate from historical sources in the Czech lands. In: Jones PD, Bradley RS, Jouzel J (eds), Climatic variations and forcing mechanisms of the last 2000 years. NATO ASI series1, vol. 41, Springer-Verlag, Berlin, p 409-431

Brázdil R, Dobrovolný P (2010) Historical climate in Central Europe during the last 500 years. In: Przybylak R, Majorowicz J, Brázdil R, Kejna M (eds), The Polish climate in the European context: an historical overview. Springer, Berlin, p 41-70

Brázdil R, Pfister C, Wanner H, von Storch H, Luterbacher J (2005) Historical climatology in Europe - The state of the art. Climatic Change 70:363-430

Brázdil R, Dobrovolný P, Luterbacher J, Moberg A, Pfister C, Wheeler D, Zorita E (2010) European climate of the past 500 years: new challenges for historical climatology. Climatic Change 101:7-40

Briffa KR, Jones PD (1992) The climate of Europe during the 1810s with special reference to 1816. In: Harington CR (ed), The Year without a Summer? World Climate in 1816, Canadian Museum of Nature

Briffa KR, Jones PD, Bartholin TS, Eckstein D, Schweingruber FH, Karlén W, Zetterberg P, Eronen M (1992) Fennoscandian summers from $\mathrm{AD}$ 500: temperature changes on short and long timescales. Clim Dynam 7:111-119
Büntgen U, Tegel W (2011) European tree-ring data and the Medieval Climate Anomaly. PAGES news 19:14-15

Büntgen U, Esper J, Frank DC, Nicolussi K, Schmidhalter M (2005) A 1052-year tree-ring proxy for Alpine summer temperatures. Clim Dynam 25:141-153

Büntgen U, Frank DC, Nievergelt D, Esper J (2006) Summer temperature variations in the European Alps, AD 755-2004. J Climate 19:5606-5623

Büntgen U, Frank DC, Kaczka RJ, Verstege A, Zwijacz-Kozica T, Esper J (2007) Growth responses to climate in a multi-species treering network in the Western Carpathian Tatra Mountains, Poland and Slovakia. Tree Physiol 27:689-702

Büntgen U, Trouet V, Frank D, Leuschner HH, Friedrichs D, Luterbacher J, Esper J (2010) Tree-ring indicators of German summer drought over the last millennium. Quaternary Sci Rev 29:1005-1016

Büntgen U, Raible C, Frank D, Helama S, Cunningham L, Hofer D, Nievergelt D, Verstege A, Stenseth N, Esper J (2011a) Causes and consequences of past and projected Scandinavian summer temperatures, 500-2100 AD. PLoS ONE 6:e25133. doi:10.1371/journal. pone. 0025133

Büntgen U, Tegel W, Nicolussi K, McCormick M, Frank D, Trouet V, Kaplan JO, Herzig F, Heussner K-U, Wanner H, Luterbacher J, Esper J (2011b) 2500 years of European climate variability and human susceptibility. Science 331:578-582

Büntgen U, Brázdil R, Heussner K-U, Hofmann J, Kontic R, Tyncl T, Pfister C, Chromá K, Tegel W (2011c) Combined dendrodocumentary evidence of Central European hydroclimatic springtime extremes over the last millennium. Quaternary Sci Rev 30:3947-3959

Büntgen U, Kaczka RJ, Trnka M, Rigling A (2012) Complex climate sensitivity of Carpathian cliff site pine growth. Agr Forest Meteorol 160:100-109

Chernavskaya M (1996) Climate of European Russia over the two past millennia. In: Obrębska-Starkel B, Niedźwiedź T (eds), Proceedings of the International conference on climate dynamics and the global change perspective, Cracov, 17-20 October 1995. Institute of Geography of the Jagiellonian University, Prace Geograficzne 102:493-496

Christiansen B, Ljungqvist FC (2011) Reconstruction of the extratropical $\mathrm{NH}$ mean temperature over the last millennium with a method that preserves low-frequency variability. J Climate 24:6013-6034

Cowie J (2007) Climate Change: Biological and Human Aspects. Cambridge University Press, Cambridge

Crowley TJ (2000) Causes of climate change over the past 1000 years. Science 289:270-277

Crowley TJ, Lowry T (2000) How warm was the Medieval Warm Period? Ambio 29:51-54

Dobrovolný P, Moberg A, Brázdil R, Pfister C, Glaser R, Wilson R, van Engelen A, Limanówka D, Kiss A, Halíčková M, Macková J, Riemann D, Luterbacher J, Böhm R (2010) Monthly, seasonal and annual temperature reconstructions for Central Europe derived from documentary evidence and instrumental records since AD 1500. Climatic Change 101:69-107

Eriksson Ch, Omsted A, Overland JE, Percival DB, Mofjeld HO (2007) Characterizing of European sub-Arctic winter climate since 1500 using ice, temperature, and atmospheric circulation time series. J Climate 20:5316-5334

Esper J, Frank DC (2009) The IPCC on a heterogeneous Medieval Warm Period. Climatic Change 94:267-273

Esper J, Büntgen U, Timonen M, Frank DC (2012) Variability of extremes of northern Scandinavian summer temperatures over the past two millennia. Global Planet Change 88-89:1-9

Folland CK, Karl TR, Vinnikov KYa (1990) Observed climate variations and change. In: Houghton JT, Jenkins GJ, Ephraums JJ 
(eds), Climate change. The IPCC scientific assessment. Cambridge University Press, p 195-238

Glaser R (2008) Klimageschichte Mitteleuropas. 1200 Jahre Wetter, Klima, Katastrophen. [History of Climate for Central Europe: 1200 years of weather, climate and catastrophes], Primus Verlag, Wissenschaftliche Buchgesellschaft, Darmstadt

Glaser R, Riemann D (2009) A thousand-year record of temperature variations for Germany and Central Europe based on documentary data. J Quaternary Sci 24:437-449

Glaser R, Riemann D, Schönbein J, Barriendos M, Brázdil R, Bertolin C, Camuffo C, Deutsch M, Dobrovolný P, van Engelen A, Enzi S, Halíčková M, Koenig SJ, Kotyza O, Limanowka D, Macková J, Sghedoni M, Martin B, Himmelsbach I (2010) The variability of European floods since AD 1500. Climatic Change 101:235-256

Gouirand I, Linderholm HW, Moberg A, Wohlfarth B (2008) On the spatiotemporal characteristics of Fennoscandian tree-ring based summer temperature reconstructions. Theor Appl Climatol 91:1-25

Grove JM (1988) The Little Ice Age. Methuen \& Co., London, New York

Grudd H (2008) Torneträsk tree-ring width and density AD 500-2004: a test of climatic sensitivity and a new 1500-year reconstruction of north Fennoscandian summers. Clim Dynam 31:843-857

Gunnarson BE, Linderholm HW (2002) Low-frequency summer temperature variation in central Sweden since the tenth century inferred from tree rings. Holocene 12:667-671

Hansson D, Gustafsson E (2011) Salinity and hypoxia in the Baltic Sea since AD 1500. J Geophys Res 116:C03027. doi:10.1029/ 2010JC006676

Hansson D, Omstedt A (2008) Modelling the Baltic Sea ocean climate on centennial time scale: Temperature and sea ice. Clim Dynam 30:763-778

Hansson D, Eriksson C, Omstedt A, Chen D (2011) Reconstruction of river runoff to the Baltic Sea, AD 1500-1995. Int J Climatol 31:696-703

Helama S, Lindholm M, Timonen M, Meriläinen J, Eronen M (2002) The supra-long Scots pine tree-ring record for Finnish Lapland: Part 2 , interannual to centennial variability in summer temperatures for 7500 years. Holocene 12:681-687

Helama S, Timonen M, Lindholm M, Merilainen J, Eronen M (2005) Extracting long-period climate fluctuations from tree-ring chronologies over timescales of centuries to millennia. Int $\mathbf{J}$ Climatol 25:1767-1779

Helama S, Meriläinen J, Tuomenvirta H (2009a) Multicentennial megadrought in northern Europe coincided with a global El NiñoSouthern Oscillation drought pattern during the Medieval Climate Anomaly. Geology 37:175-178.

Helama S, Timonen M, Holopainen J, Ogurtsov MG, Mielikäinen K, Eronen M, Lindholm M, Meriläinen J (2009b) Summer temperature variations in Lapland during the Medieval Warm Period and the Little Ice Age relative to natural instability of thermohaline circulation on multi-decadal and multi-centennial scales. J Quaternary Sci 24:450-456

Holmström L (2011) Discussion of: A statistical analysis of multiple temperature proxies: are reconstructions of surface temperatures over the last 1000 years reliable? Ann Appl Stat 5:71-75

Holopainen J, Helama S (2009) Little Ice Age farming in Finland: preindustrial agriculture on the edge of the Grim Reaper's Scythe. Hum Ecol 37:213-225

Jevrejeva S (2001) Severity of winter seasons in the northern Baltic Sea between 1529 and 1990: reconstruction and analysis. Clim Res 17:55-62

Jones PD, Briffa KR (2006) Unusual climate in northwest Europe during the period 1730 to 1745 based on instrumental and documentary data. Climatic Change 79:361-379
Jones PD, Mann ME (2004) Climate over the past millennia. Rev Geophys 42:RG2002. doi:10.1029/2003RG000143

Jones PD, Briffa KR, Barnett TP, Tett SFB (1998) High-resolution palaeoclimatic records for the last millennium: interpretation, integration and comparison with General Circulation Model control-run temperatures. Holocene 8:455-471

Jones PD, Ogilvie AEJ, Davies TD, Briffa KR (eds) (2001a) History and climate. Memories of the future? Kluwer/Plenum Publishers, New York, Boston, Dordrecht, London, Moscow

Jones PD, Osborn TJ, Briffa KR (2001b) The evolution of climate over the last millennium. Science 292:662-667

Jones PD, Briffa KR, Osborn TJ et al (2009) High-resolution palaeoclimatology of the last millennium: a review of current status and future prospects. Holocene 19:3-49

Jönsson K, Nilsson Ch (2009) Scott Pine (Pinus sylvestris L.) on shingle fields: A dendrochronologic reconstruction of early summer precipitation in mideast Sweden. J Climate 22:4710-4722

Kalela-Brundin M (1999) Climatic information from tree-rings of Pinus sylvestris $\mathrm{L}$. and a reconstruction of summer temperatures back to AD 1500 in Femundsmarka, eastern Norway, using partial least squares regression (PLS). Holocene 9:59-77

Klimenko I, Solomina O (2010) Climatic variations in the east European plain during the last millennium: state of the art. In: Przybylak R et al (eds), The Polish Climate in the European Context: An Historical Overview, Springer, Dordrecht, Heidelberg, London, New York, p 71-101

Klimanov VA, Koff T, Punning Y-M (1985) Climatic conditions in the north-west Baltic during the past 2000 years. Izvestiya of Russian Academy of Sciences Geographical Series 1: 89-96 (in Russian)

Koprowski M, Przybylak R, Zielski A, Pospieszyńska A (2012) Tree rings of Scots pine (Pinus sylvestris L.) as a source of information about past climate in northern Poland. Int J Biometeorol 56:1-10

Korhola A, Weckström J, Holmström L, Erästö P (2000) A quantitative Holocene climatic record from diatoms in northern Fennoscandia. Quaternary Res 54:284-294

Korhola A, Vasko K, Toivonen HTT, Olander H (2002) Holocene temperature changes in northern Fennoscandia reconstructed from chironomids using Bayesian modelling. Quaternary Sci Rev 21:1841-1860

Koslowski G, Glaser R (1999) Variations in reconstructed ice winter severity in the western Baltic from 1501 to 1995 and their implications for the North Atlantic Oscillation. Climatic Change 41:175-191

Lamb HH (1977) Climate: present, past and future. Climatic history and the future, Vol 2, Methuen \& Co Ltd London

Lamb HH (1982) Climate: history and the modern world. Methuen, London

Lamentowicz M, Cedro A, Miotk-Szpiganowicz G, Mitchell EAD, Pawlyta J, Goslar T (2008) Last millennium palaeoenvironmental changes from a Baltic bog (Poland) inferred from stable isotopes, pollen, plant macrofossils and testate amoebae. Palaeogeogr Palaeocl 265:93-106

Lamentowicz M, Milecka K, Lamentowicz L, Galka M, Cedro A, Pawlyta J, Piotrowska N, Van der Knaap WO (2009) Climate and human induced hydrological change since AD 800 in an ombrotrophic mire in Pomerania (N Poland) tracked by testate amoebae, macro-fossils, pollen, and tree-rings of pine. Boreas 38:214-229

Leijonhufvud L, Wilson R, Moberg A, Söderberg J, Retsö D, Söderlind U (2010) Five centuries of Stockholm winter/spring temperatures reconstructed from documentary evidence and instrumental observations. Climatic Change 101:109-141

Limanówka D (2001) Rekonstrukcja warunków klimatycznych Krakowa w pierwszej polowie XVI wieku (Reconstruction of climatic conditions in Cracow in the first half of the 16th century). Instytut 
Meteorologii i Gospodarki Wodnej, Warszawa, Materiały Badawcze IMGW, Ser. Meteorologia 33:25-32

Linderholm HW, Gunnarson BE (2005) Summer climate variability in west-central Fennoscandia during the past 3600 years. Geogr Ann A $87: 231-241$

Lindholm M, Ogurtsov M, Aalto T, Jalkanen R, Salminen H (2009) A summer temperature proxy from height increment of Scots pine since 1561 at the northern timberline in Fennoscandia. Holocene 19:1131-1138

Lindholm M, Jalkanen R, Salminen H, Aalto T, Ogurtsov M (2011) The height-increment record of summer temperature extended over the last millennium in Fennoscandia. Holocene 21:319-326

Ljungqvist FC (2010) A new reconstruction of temperature variability in the extratropical Northern Hemisphere during the last two millennia. Geogr Ann A 92:339-351

Ljungqvist FC, Krusic PJ, Brattström G, Sundqvist H (2012) Northern hemisphere temperature patterns in the last 12 centuries. Clim Past 8:227-249

Luterbacher J, Rickli R, Xoplaki E, Tinguely C, Beck C, Pfister C, Wanner H (2001) The Late Maunder Minimum (1675-1715) - a key period for studying decadal scale climatic change in Europe. Climatic Change 49:441-462

Luterbacher J, Dietrich D, Xoplaki E, Grosjean M, Wanner H (2004) European seasonal and annual temperature variability, trends and extremes since 1500. Science 303:1499-1503

Luterbacher J, Xoplaki E, Küttel M, Zorita E,González-Rouco FJ, Jones PD, Stössel M, Rutishauser T, Wanner H, Wibig J, Przybylak $\mathrm{R}$ (2010) Climate change in Poland in the past centuries and its relationship to European climate: evidence from reconstructions and coupled climate models. In: Przybylak R et al (eds), The Polish climate in the European context: an historical overview. Springer, Berlin: 3-39

Luoto TP, Helama S (2010) Palaeoclimatological and palaeolimnological records from fossil midges and tree-rings: the role of the North Atlantic Oscillation in eastern Finland through the Medieval Climate Anomaly and Little Ice Age. Quaternary Sc Rev 29:2411-2423

Majorowicz J (2010) The climate of Europe in recent centuries in the context of the climate of mid to high latitude Northern Hemisphere from borehole temperature logs. In: Przybylak R, Majorowicz J, Brázdil R, Kejna $M$ (eds) The Polish climate in the European context: an historical overview. Springer, Berlin, p 103-126

Majorowicz J, Šafanda J, Przybylak R, Wójcik G (2004) Ground surface temperature history in Poland in the 16th-20th centuries derived from the inversion of geothermal profiles. Pure Appl Geophys 161:351-363

Manley G (1974) Central England temperatures: monthly means 1659 to 1973. Q J Roy Meteor Soc 100:389-405

Mann ME, Jones PD (2003) Global surface temperatures over the past two millennia. Geophys Res Lett 30:1820. doi:10.1029/ 2003GL017814

Mann ME, Bradley RS, Hughes MK (1998) Global-scale temperature patterns and climate forcing over the past 6 six centuries. Nature 392:779-787

Mann ME, Bradley RS, Hughes MK (1999) Northern hemisphere temperatures during the past millennium: inferences, uncertainties, and limitations. Geophys Res Lett 26:759-762

Mann ME, Zhang Z, Hughes MK, Bradley RS, Miller SK, Rutherford S, Ni F (2008) Proxy-based reconstructions of hemispheric and global surface temperature variations over the past two millennia. PNAS 105:13252-13257

Moberg A, Bergström H, Krigsman JR, Svanered O (2002) Daily air temperature and pressure series for Stockholm (1756-1998). Climatic Change 53:171-212
Moberg A, Tuomenvirta H, Nordli Ø (2005) Recent climatic trends. In: Seppälä M (ed), Physical geography of Fennoscandia. Oxford Regional Environments Series. Oxford University Press, Oxford, p 113-133

Moberg A, Gouirand I, Schoning K, Wohlfarth B, Kjellström E, Rummukainen M, de Jong R, Linderholm H, Zorita E (2006) Climate in Sweden during the past millennium - evidence from proxy data, instrumental data and model simulations. SKB technical report TR-06-35. Swedish Nuclear Fuel and Waste Management Co, Stockholm

NCR (2006) Surface temperature reconstructions for the last 2,000 years. National Research Council, Washington DC, National Academies Press

Niedźwiedź T (2004) Rekonstrukcja warunków termicznych lata w Tatrach od 1550 roku (Reconstruction of summer temperature in the Tatra Mountains since 1550). In: Kotarba A (ed.) Rola małej epoki lodowej w przekształcaniu środowiska przyrodniczego Tatr. Prace Geograficzne 197:57-88

Neumann J (1978) Great historical events that were significantly affected by the weather: 3 , the cold winter of $1657-58$, the Swedish army cross Denmark's frozen sea areas. B Am Meteorol Soc 59:1432-1437

Nordli Ø, Lie Ø, Nesje A, Dahl SO (2003) Spring-summer temperature reconstruction in western Norway 1734-2003: a data-synthesis approach. Int J Climatol 23:1821-1841

Nowosad W, Przybylak R, Marciniak K, Syta K (2007) Diariusz Jana Antoniego Chrapowickiego jako źródło do badań klimatu Rzeczypospolitej w II połowie XVII w. (Diary of Jan Antoni Chrapowicki as a source for investigation of the climate of Poland in the second part of $17^{\text {th }}$ century). Klio 9:21-60 (in Polish)

Ogurtsov M, Raspopov O, Helama S, Oinonen M, Lindholm M, Jungner H, Meriläinen J (2008) Climatic variability along a northsouth transect of Finland over the last 500 years: signature of solar influence or internal climate oscillations? Geogr Ann A 90:141-150

Ogurtsov MG, Jungner H, Helama S, Lindholm M, Oinonen M (2011) Paleoclimatological evidence for unprecedented recent temperature rise at the extratropical part of the Northern Hemisphere. Geogr Ann A 93:17-26

Pfister C (1992) Monthly temperature and precipitation in central Europe 1525-1979: quantifying documentary evidence on weather and its effects. In: Bradley RS, Jones PD (eds), Climate since AD 1500, Routledge, London, p 118-142

Pfister C (1999) Wetternachhersage, 500 Jahre Klimavariationen und Naturkatastrophen (1496-1995). Verlag Paul Haupt, Bern, Stuttgart, Wien

Przybylak R (2007) The change in the Polish climate in recent centuries. Pap Global Change IGBP 14:7-23

Przybylak R (2011) Changes in Poland's climate over the last millennium. Czasopismo Geograficzne 82:23-48

Przybylak R, Marciniak K (2010) Climate changes in the central and north-eastern parts of the Polish-Lithuanian commonwealth from 1656 to 1685. In: Przybylak R, Majorowicz J, Brázdil R, Kejna M (eds), The Polish Climate in the European Context: An Historical Overview, Springer Science + Business Media B.V. Dordrecht, Heidelberg, London, New York, p 423-443

Przybylak R, Majorowicz J, Wójcik G, Zielski A, Chorążyczewski W, Marciniak K, Nowosad W, Oliński P, Syta K (2005) Temperature changes in Poland from the $16^{\text {th }}$ to the $20^{\text {th }}$ centuries. Int J Climatol 25:773-791

Przybylak R, Majorowicz J, Brázdil R, Kejna M (eds) (2010) The Polish climate in the European context: An historical overview. Springer Science + Business Media B.V. Dordrecht, Heidelberg, London, New York 
Ralska-Jasiewiczowa M, Goslar T, Madeyska T, Starkel L (eds) (1998) Lake Gościąż, central Poland a monographic study. Szafer Institute of Botany, Polish Academy of Sciences, Kraków

Rojecki A (ed) (1965) Wyjątki ze źródeł historycznych o nadzwyczajnych zjawiskach hydrologiczno-meteorologicznych na ziemiach polskich w wiekach od X do XVI (Selection of historical sources about unusual hydro-meteorological events on the Polish territory from 10th to 16th centuries). Selection and Polish translation: Girguś R and Strupczewski W, PIHM, Wydawnictwa Komunikacji i Łączności, Warszawa (in Polish and original texts mainly in Latin and German)

Schimanke S, Meier HEM, Kjellström E, Strandberg G, Hordoir R (2012) The climate of the Baltic Sea region during the last millennium simulated with a regional climate model. Clim Past 8:1419-1433

Seinä A, Palosuo E (1996) The classification of the maximum annual extent of ice cover in the Baltic Sea 1720-1995. MERI 27:79-91

Starkel L (2001) Extreme rainfalls and river floods in Europe during the last millennium. Pap Global Change IGBP 8:69-79

Starkel L, Pazdur A, Pazdur MF, Wicik B, Więckowski K (1996) Lakelevel and groundwater-level changes in the Lake Gościąż area, Poland: paleoclimatic implications. Holocene 6:213-224
Szychowska-Krąpiec E (2010) Long-term chronologies of pine (Pinus sylvestris L.) and fir (Abbies alba Mill.) from the Małopolska region and their paleoclimatic interpretation. Folia Quat 79:5-124

Tarand A, Nordli $\varnothing$ (2001) The Tallinn temperature series reconstructed back half a millennium by use of proxy data. Climatic Change 48:189-199

von Rudloff H (1967) Die schwankungen und pendelungen des klimas in Europa sei dem beginn der regelmässigen Instrumenten-Beobachtungen (1670). Friedrich Vieweg \& Sohn, Braunschweig

von Storch H, Zorita E, Jones JM, Dimitriev Y, González-Rouco F, Tett SFB (2004) Reconstructing past climate from noisy data. Science 306:679-682

Weckström J, Korhola A, Erästö P, Holmström L (2006) Temperature patterns over the past eight centuries in northern Fennoscandia inferred from sedimentary diatoms. Quaternary Res 66:78-86

Xoplaki E, Luterbacher J, Paeth H, Dietrich D, Steiner N, Grosjean M, Wanner H (2005) European spring and autumn temperature variability and change of extremes over the last half millennium. Geophys Res Lett 32:L15713. doi:10.1029/2005GL023424

Zorita E, González-Rouco F, von Storch H (2007) Comments on 'Testing the fidelity of methods used in proxy-based reconstructions of past climate'. J Climate 20:3693-3698 